\title{
Establishment of Pluripotent Cell Lines from Vertebrate Species - Present Status and Future Prospects
}

\author{
Katja Prelle $^{a}$ Ivan M. Vassiliev ${ }^{b, 1}$ Svetlana G. Vassilieva ${ }^{b}$ Eckhard Wolfa \\ Anna M. Wobus ${ }^{b}$ \\ a Department of Molecular Animal Breeding and Genetics, Gene Centre, Ludwig Maximilian University, Munich and \\ bIn Vitro Differentiation Group, IPK Gatersleben, Germany
}

\section{Key Words}

Stem cells, embryonic $\cdot$ Primordial germ cells · Domestic animals $\cdot$ Gene transfer $\cdot$ Nuclear transfer

\begin{abstract}
Pluripotent embryonic stem (ES) cells are undifferentiated cell lines derived from early embryos and are capable of unlimited undifferentiated proliferation in vitro. They retain the ability to differentiate into all cell types including germ cells in chimeric animals in vivo, and can be induced to form derivatives of all three germ layers in vitro. Mouse ES cells represent one of the most important tools in genetic research. Major applications include the targeted mutation of specific genes by homologous recombination and the discovery of new genes by gene trap strategies. These applications would be of high interest for other model organisms and also
\end{abstract}

K.P. and I.M.V. contributed equally to this work.

1 Present address: Institute of Physiological Chemistry, Martin Luther University, Halle/Saale (Germany).

\begin{tabular}{ll}
\hline KARGER & ( 1999 S. Karger AG, Basel \\
1422-6405/99/1654-0220\$17.50/0 \\
$\begin{array}{l}\text { Fax +4161306 12 34 } \\
\begin{array}{l}\text { E-Mail karger@karger.ch } \\
\text { www.karger.com }\end{array}\end{array}$ & $\begin{array}{l}\text { Accessible online at: } \\
\text { www.karger.com/journals/cto }\end{array}$
\end{tabular}

for livestock species. However, in spite of tremendous research activities, no proven ES cells colonizing the germ line have been established for vertebrate species other than mouse and chicken thus far. This review summarizes the current status of deriving pluripotent embryonic stem cell lines from vertebrates and recent developments in nuclear transfer technology, which may provide an alternative tool for genetic modification of livestock animals.

\begin{tabular}{ll}
\hline Abbreviations used in this paper \\
\hline AP & alkaline phosphatase \\
bFGF & basic fibroblast growth factor \\
BRL & Buffalo rat liver \\
EG & embryonic germ cells \\
ES & embryonic stem cells \\
ICM & inner cell mass \\
IL & interleukin \\
LIF & leukemia inhibitory factor \\
neo & neomycin \\
PGC & primordial germ cells \\
SCF & stem cell factor \\
SSEA & stage-specific embryonic antigen
\end{tabular}

Dr. Katja Prelle

Department of Molecular Animal Breeding and Genetics

Ludwig Maximilian University Munich, Hackerstrasse 27

D-85764 Oberschleissheim (Germany)

Tel.+4989 31573233, Fax+4989 3152799, E-Mail k.prelle@gen.vetmed.uni-muenchen.de 
Table 1. Toti-/pluripotency of cells and nuclei [according to Campbell and Wilmut, 1997]

\begin{tabular}{|c|c|c|c|c|}
\hline & \multicolumn{2}{|l|}{ Cells } & \multicolumn{2}{|l|}{ Nuclei } \\
\hline & totipotency & pluripotency & totipotency & pluripotency \\
\hline Definition & $\begin{array}{l}\text { Ability to form a whole } \\
\text { organism }\end{array}$ & $\begin{array}{l}\text { Ability to differentiate into } \\
\text { many or all tissues including } \\
\text { the germ line of chimeric } \\
\text { animals }\end{array}$ & $\begin{array}{l}\text { Ability to support full-term } \\
\text { development of an embryo } \\
\text { reconstructed by nuclear } \\
\text { transfer }\end{array}$ & $\begin{array}{l}\text { Ability to partially support } \\
\text { the development of nuclear } \\
\text { transfer embryos }\end{array}$ \\
\hline Examples & $\begin{array}{l}\text { Blastomeres of early } \\
\text { cleavage } \\
\text { stage embryos }{ }^{1}\end{array}$ & $\begin{array}{l}\text { ICM cells, EC cells, ES cells, } \\
\text { EG cells }\end{array}$ & $\begin{array}{l}\text { Sheep: cultured embryonic } \\
\text { disc cells, fetal fibroblasts, } \\
\text { mammary gland cells } \\
\text { Cattle: fetal fibroblasts, } \\
\text { germ cells, postnatal skin } \\
\text { fibroblasts, uterine cells } \\
\text { Mouse: cumulus cells } \\
\text { [reviewed in Wolf et al., 1998] }\end{array}$ & $\begin{array}{l}\text { Cattle: oogonia, } \\
\text { trophoblastic cells } \\
\text { Mouse: Sertoli cells, neurons } \\
\text { [reviewed in Wolf et al., 1998] }\end{array}$ \\
\hline Technology & $\begin{array}{l}\text { Embryo splitting, } \\
\text { blastomere separation }\end{array}$ & $\begin{array}{l}\text { Aggregation with morulae, } \\
\text { injection into blastocysts }\end{array}$ & Nuclear transfer & Nuclear transfer \\
\hline
\end{tabular}

$\mathrm{EC}=$ Embryonic carcinoma cells

1 Germ line-competent ES and EG cells were also classified as totipotent by some authors.

\section{Pluripotent Cell Lines in Mouse}

Cells capable of forming a whole conceptus are termed 'totipotent', whereas 'pluripotent' cells have the ability to contribute to several tissues of the fetus and in some cases to the extraembryonic membranes when used for chimera formation [reviewed in Campbell and Wilmut, 1997]. The developmental potential of cells has to be separated from that of nuclei, which may be derived from differentiated cells but reprogrammed by nuclear transfer and thus give rise to a whole organism (table 1).

In mice, pluripotent embryonic cells were first isolated from teratocarcinomas, which comprise a mixture of differentiated cell types including derivatives of all germ layers and remaining undifferentiated (malignant) stem cells [Martin and Evans, 1975]. These embryonic carcinoma cells show several disadvantages, like overt karyotypic abnormalities and low germ line colonization due to the deregulated environment within teratocarcinomas.

Embryonic stem (ES) cells may be derived from 8-cell embryos [Wobus et al., 1991; Delhaise et al., 1996] or dissociated blastomeres of morulae [Eistetter, 1989], but are most frequently established from the inner cell mass (ICM) of blastocysts [Evans and Kaufman, 1981; Martin, 1981] or the pluripotent cell population of the primitive ectoderm of delayed implanting blastocysts [Brook and Gardner, 1997]. Most ES cell lines were isolated according to standard protocols [Robertson, 1997] from embryos of the inbred strain $129 \mathrm{~Sv}$, although selection strategies have been developed to allow isolation of ES cells from embryos with a normally nonpermissive genetic background [McWhir et al., 1996]. Undifferentiated proliferation of ES cells in culture was initially achieved by using feeder cells [primary mouse embryonic fibroblasts, Wobus et al., 1984; STO cells, Evans and Kaufman, 1981; Robertson, 1987] or media conditioned by Buffalo rat liver (BRL) cells [Smith and Hooper, 1987]. The differentiation-inhibiting activity in both systems has been identified as leukemia inhibitory factor (LIF) [Smith et al., 1988]. The recombinant protein maintains pluripotency of ES cells in the absence of feeder cells [Nichols et al., 1990]. Alternatively, other cytokines acting through the gp130 signal transduction pathway, including interleukin6 (IL-6), oncostatin $M$ and ciliary neurotrophic factor [Conover et al., 1993; Nichols et al., 1994; Rose and Bruce, 1994; Wolf et al., 1994; reviewed in Wolf et al., 1996], have successfully been used to sustain undifferentiated murine ES cells capable of differentiating in vitro and in vivo. 
A third class of pluripotent cells in mice is derived from primordial germ cells (PGCs) which migrate from the base of the allantois through the hindgut epithelium and the dorsal mesentery into the gonadal anlage [Eddy et al., 1981]. After a period of intragonadal mitotic proliferation the male germ cells enter a quiescent period of mitotic arrest in the testis, while the female PGCs undergo rapid mitotic divisions before entering the meiotic arrest in the ovary [reviewed in Wylie, 1993]. Embryonic germ (EG) cells can be derived from pre- and postmigratory PGCs by using a combination of LIF, basic fibroblast growth factor (bFGF) and stem cell factor (SCF) in the culture medium [Matsui et al., 1992; Resnick et al., 1992; Stewart et al., 1994] and behave in a similar way as ES cells when injected into host blastocysts [Matsui et al., 1992] and upon induced differentiation in vitro [Rohwedel et al., 1996]. PGCs are available in larger numbers per fetus, but the extent of methylation of specific genes may differ compared to ICM cells [Solter, 1998].

\section{Characteristics of Pluripotent Embryonic Cell Lines in Mouse}

Pluripotent cells exhibit morphological characteristics, i.e. a high nuclear:cytoplasm ratio and growth in compact, multilayered colonies. They show alkaline phosphatase (AP) activity [Resnick et al., 1992] and express highly conserved epitope markers, like stage-specific embryonic antigen-1 (SSEA-1) [Solter and Knowles, 1978] or ECMA7 [Pease et al., 1990], and the germ line-specific transcription factor Oct-4 [Schöler et al., 1989]. In addition, a short G1 cell cycle phase [Rohwedel et al., 1996] and high levels of telomerase activity [Thomson et al., 1998] are highly correlated with the undifferentiated state of ES cells.

Pluripotent cells can be stimulated to differentiate in vitro into various cell types by removing feeder cells and differentiation-inhibiting cytokines [reviewed in Pedersen, 1994], or by adding specific differentiation-inducing substances [e.g. retinoic acid, Wobus et al., 1994, 1997a; see Rohwedel et al., 1999]. Maintained in suspension culture or 'hanging drops' [Wobus et al., 1984], pluripotent cells form embryo-like aggregates, so-called 'embryoid bodies', consisting of derivatives of the three embryonic germ layers [Doetschman et al., 1985; Rohwedel et al., 1996, reviewed in Wobus and Guan, 1998].

In vivo differentiation of pluripotent cells occurs after transplantation to syngenic or immunodeficient mice, where they form teratocarcinomas or teratomas [Evans and Kaufman, 1981]. When combined with normal embryos via blastocyst injection [Bradley et al., 1984] or morula aggregation [Wood et al., 1993], these cells contribute to all tissues and organs including the germ line of a chimeric individual, giving rise to functional gametes [Labosky et al., 1994]. When 'target' ES cells were aggregated with 'carrier' tetraploid embryos [Nagy et al., 1990], the pluripotent cells formed the adult organism without any participation of tetraploid host embryo cells [Wang et al., 1997].

\section{Pluripotent Embryonic Cell Lines in Other Vertebrate Species}

Murine pluripotent embryo-derived cell lines offer a suitable model system for investigating cellular differentiation of the vertebrate organism [Wobus et al., 1997b] and provide an important system for site-specific introduction of genetic alterations by gene targeting technology [Thomas and Capecchi, 1987] as well as for screening developmental genes by gene trap experiments [reviewed in Evans et al., 1997]. Because of these powerful applications, many attempts have been made to establish ES and EG cell technology in other species. Although many of these embryo-derived cell lines resemble - at least in part - mouse ES cell morphology and epitope profiles [Van Stekelenburg-Hamers et al., 1995; Etches et al., 1996] and have the ability to differentiate in vitro, there is no published data reporting liveborn, fertile germ line chimeras in mammalian species other than mouse (table 2). Establishment of pluripotent cell lines especially from mammals other than mice would have a great impact on studies of early developmental processes, such as cell lineage commitment [Beddington and Robertson, 1989] and genomic imprinting [Mann et al., 1990], and especially on genetic modification [Wheeler and Choi, 1997] and nuclear transfer in livestock species [Modlinski et al., 1996].

\section{Fish}

Fish are excellent vertebrate model systems, especially for research fields of developmental biology, i.e. the molecular analysis of normal and disturbed development.

In zebrafish, blastula-derived embryonic cell lines have been maintained undifferentiated for more than 40 passages using trout embryo extract and serum added to BRL cell-conditioned medium [Collodi et al., 1992]. When using neomycin (neo)-transfected cells, the foreign neo-specific DNA sequences were detected in juvenile 
Table 2. Establishment of pluripotent embryonic cell lines from vertebrate species (except mouse)

\begin{tabular}{|c|c|c|c|c|}
\hline Species & Cell source & ES-like characteristics & In vivo differentiation & References \\
\hline Medakafish & Midblastulae & AP activity, EB formation & Transgenic chimeric fry & Hong et al. [1998] \\
\hline Zebrafish & Midblastulae & $\begin{array}{l}\text { AP activity, in vitro } \\
\text { differentiation }\end{array}$ & $\begin{array}{l}\text { Transgenic chimeric } \\
\text { juveniles }\end{array}$ & Sun et al. [1995] \\
\hline \multirow[t]{2}{*}{ Chicken } & Stage $\mathrm{X}$ blastoderm & $\begin{array}{l}\text { AP activity, SSEA-1, SSEA-3 } \\
\text { and ECMA- } 7 \text { expression }\end{array}$ & Germ line chimeras & Pain et al. [1996] \\
\hline & 5-day genital ridges & Morphology & Germ line chimeric chicken & Chang et al. [1997] \\
\hline \multirow[t]{2}{*}{ Rabbit } & 5-day intact embryos & EB formation & Coat color chimeras & Schoonjans et al. [1996] \\
\hline & $\begin{array}{l}18 \text { - to } 22 \text {-day genital } \\
\text { ridges }\end{array}$ & SSEA-1 expression, AP activity & Coat color chimeras & Moens et al. [1997] \\
\hline Rat (?) & Blastocysts & $\begin{array}{l}\text { AP activity, SSEA-1 expression, } \\
\text { EB formation }\end{array}$ & $\begin{array}{l}\text { Coat color chimeras (not } \\
\text { proven in independent } \\
\text { repeated experiments) }\end{array}$ & Iannaccone et al. [1994] \\
\hline Syrian hamster & 3-day blastocysts & EB formation & n.d. & Doetschman et al. [1988] \\
\hline Mink & 7-day blastocysts & $\begin{array}{l}\text { EB formation, teratoma } \\
\text { formation }\end{array}$ & n.d. & Sukoyan et al. [1993] \\
\hline \multirow[t]{2}{*}{ Pig } & Blastocysts & EB formation & Coat color chimeras & Wheeler [1994] \\
\hline & $\begin{array}{l}25 \text { - to } 27 \text {-day genital } \\
\text { ridges }\end{array}$ & AP activity, EB formation & Transgenic chimeric piglet & Piedrahita et al. [1998] \\
\hline \multirow[t]{2}{*}{ Cattle } & $\begin{array}{l}\text { Blastocysts derived by } \\
\text { fibroblast cloning }\end{array}$ & Morphology & Transgenic chimeric calves & Cibelli et al. [1998a] \\
\hline & 45-day genital ridges & Morphology, pseudopodia & Cloned bull calf & Strelchenko et al. [1998] \\
\hline Sheep & 8-day blastocysts & Morphology & Cloned lambs & Wells et al. [1997] \\
\hline Rhesus monkey & 6-day blastocysts & $\begin{array}{l}\text { AP activity, SSEA- } 3 \text { and } \\
\text { SSEA- } 4 \text { expression, in vitro }\end{array}$ & n.d. & Thomson et al. [1995] \\
\hline Common marmoset & 8-day blastocysts & $\begin{array}{l}\text { differentiation, EB and } \\
\text { teratoma formation }\end{array}$ & n.d. & Thomson et al. [1996] \\
\hline \multirow[t]{2}{*}{ Human } & IVF blastocysts & $\begin{array}{l}\text { Morphology, telomerase } \\
\text { activity, AP activity, } \\
\text { SSEA-3 and SSEA-4 expression }\end{array}$ & n.d. & Thomson et al. [1998] \\
\hline & $\begin{array}{l}\text { 5- to 9-week genital } \\
\text { ridges }\end{array}$ & $\begin{array}{l}\text { AP activity, SSEA-1, SSEA-3 } \\
\text { and SSEA-4 expression, } \\
\text { EB formation }\end{array}$ & n.d. & Shamblott et al. [1998] \\
\hline
\end{tabular}

$\mathrm{EB}=$ Embryoid body; n.d. = not done.

fish 18 days following blastocyst injection of the ES-like cells. For a detailed analysis embryonic cells from blastula stage embryos were cultured on zebrafish embryonic fibroblasts in medium supplemented with bovine insulin, LIF, an extract of rainbow trout embryos, and trout serum [Sun et al., 1995]. The cells possessed a diploid karyotype, exhibited an ES-like morphology and high AP activity. Induced in vitro differentiation resulted in neuronal cell types. Genetically marked embryonic cells expressed the

neo gene in chimeric fish generated by blastocyst injection.

Blastomeres isolated from medakafish embryos at the midblastula stage were cultured on homologous fibroblasts with addition of carp serum, LIF and bFGF, and were maintained in culture for up to 11 passages. These cells exhibited morphological features comparable to mouse ES cells with high AP activity [Wakamatsu et al., 1994]. Differentiated derivatives induced by retinoic acid 

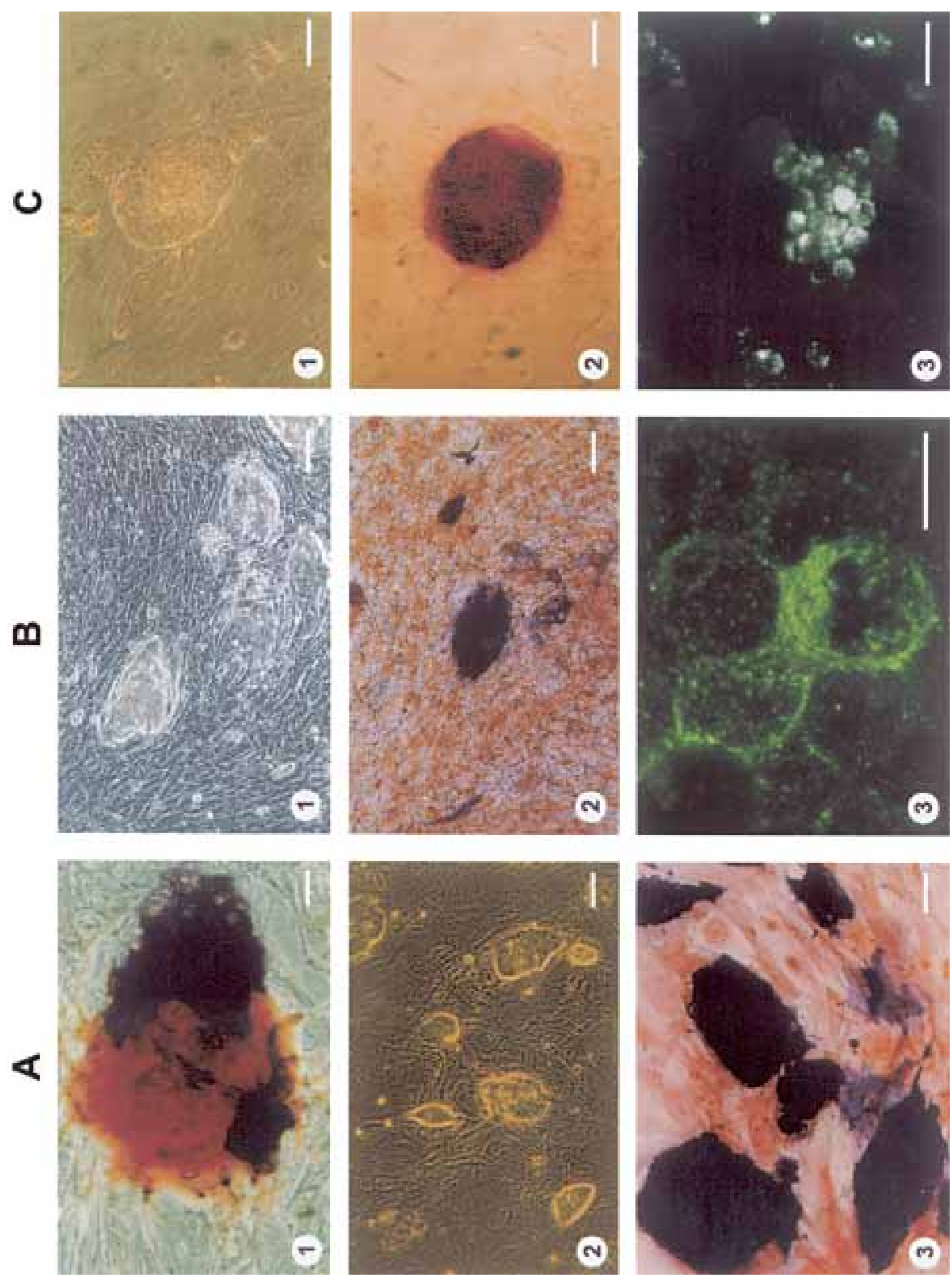
included melanocytes, neuronal and skeletal muscle-like cells.

Hong and Schartl [1996] set up conditions supporting feeder cell-free cultivation of medakafish embryonic cells isolated at the midblastula stage, which displayed features resembling mouse ES cells when cultured in medium supplemented with human bFGF and LIF, fish embryo extract, and trout serum. Continuously cultured over 18 months (100 passages), the putative medakafish ES cells formed densely packed, AP-positive colonies. In suspension culture they developed embryoid bodies and differentiated into various cell types including neuron- and fibroblast-like cells, pigment and muscle cells [Hong et al., 1996]. These ES cells were competent to form chimeras with a high contribution of the transplanted cells to numerous organs [Hong et al., 1998].

Fig. 1. Establishment of pluripotent embryonic cells in culture from rabbit, rat and pig. A Rabbit embryos (Zika ${ }^{\circledR}$ albino) as source of pluripotent ES-like cells. A1 Blastocyst outgrowth with AP-positive ICM counterstained with neutral red (ALP kit, Sigma) at the 1 day after attachment. Bar $=50 \mu \mathrm{m}$. A2 ES-like colonies at passage $7 \mathrm{cul}$ tured on rabbit embryonic fibroblasts in Dulbecco's modified Eagle's medium (DMEM)/Ham's F-12 (50:50, Sigma), supplemented with $15 \%$ fetal calf serum (FCS; Gibco BRL), $2 \mathrm{~m} M L$-glutamine (Hyclone), $0.1 \mathrm{~m} M$ nonessential amino acids (NEAA; Sigma), penicillin/ streptomycin $(100 \mathrm{IU} / 100 \mathrm{mg}$; Gibco BRL), 1\% nucleoside stock solution (Sigma) and 1,000 IU/ml murine LIF (ESGRO, Gibco BRL). Bar $=100 \mu \mathrm{m}$. A3 AP-positive rabbit ES-like colonies on embryonic fibroblasts after 17 passages. Bar $=100 \mu \mathrm{m}$. B Rat ES-like cells established from 4.5-day blastocysts (F-344), cultured on mouse embryonic fibroblasts in DMEM/Iscove's medium (50:50; Gibco BRL), supplemented with $15 \%$ FCS, NEAA ( $1 \%$ stock solution; Gibco BRL), $2 \mathrm{~m} M L$-glutamine (Gibco BRL), $0.3 \mathrm{~m} M$ each of adenosine, cytidine, guanosine and uridine (Sigma), $0.1 \mathrm{~m} M$ thymidine (Sigma), human transferrin (15 $\mu \mathrm{g} / \mathrm{ml}$; Boehringer, Mannheim), penicillin/streptomycin (50 IU/50 $\mu \mathrm{g}$; Gibco BRL), $20 \mathrm{ng} / \mathrm{ml}$ human LIF (prepared using plasmid pGEX2T.LIF-58), $450 \mu \mathrm{M}$ monothioglycerol (Sigma), and $20 \mathrm{ng} / \mathrm{ml}$ bFGF (Strathmann Biotech). B1 Compact colonies at passage 6 . Bar $=100 \mu \mathrm{m}$. B2 Histochemical staining for AP activity (ALP kit, Sigma). Bar $=100 \mu \mathrm{m}$. B3 SSEA-1 immunolabelling of rat ES-like cells (RES-6) at passage 6 after confocal laser scanning microscopy. Bar $=10 \mu \mathrm{m}$. C Porcine PGCs isolated from 27-day-old fetuses, cultured on STO feeder cells in DMEM (Gibco BRL), supplemented with 10\% FCS (Boehringer, Mannheim), 1\% NEAA (Gibco BRL), $2 \mathrm{mM}$ L-glutamine (Gibco BRL), penicillin/ streptomycin (10 IU/ $100 \mu \mathrm{g}$; Gibco BRL). C1 Multi-layered compact colonies after 28 weeks ( 15 passages) in vitro. Bar $=50 \mu \mathrm{m}$. C2 AP staining of undifferentiated porcine PGCs after 28 weeks (15 passages; ALP kit, Sigma). Bar $=50 \mu \mathrm{m}$. C3 SSEA-1 immunolabelling of porcine EG cells after 30 days in culture by confocal laser scanning microscopy. $\mathrm{Bar}=25 \mu \mathrm{m}$.

\section{Avian}

In the chicken, embryos at the designated stage $\mathrm{X}$ are composed of 40,000-80,000 morphologically undifferentiated cells [Thorval et al., 1994]. These cells, when injected into the subgerminal cavity of host embryos, were incorporated into the germ line and could subsequently contribute to melanocytes and erythrocytes [Petitte et al., 1990]. The somatic and germ line chimerism was increased when the development of recipient embryos was compromised by exposure to $\gamma$-irradiation [Carsience et al., 1993]. To propagate these putative pluripotent blastodermal cells in vitro, they were cultured for a short time (48 h) as explanted embryos, as a dispersed cell monolayer or on a mouse fibroblast feeder layer in the presence of LIF, bFGF and chicken SCF [Etches et al., 1996]. Regardless of the culture conditions, the contribution to ectoderm-derived tissues and to the germ line of chimeras produced by injection into the subgerminal cavity was reduced as compared to freshly isolated blastodermal cells. Putative avian ES cells could be maintained long-term in vitro on STO cells in medium supplemented with LIF, bFGF, SCF, oncostatin M, IL-11 and IL-6 [Pain et al., 1996]. These cells exhibited features similar to murine ES cells such as typical morphology, high AP activity, and specific epitopes such as SSEA-1, SSEA-3, ECMA-7 and EMA-1. They presented high capacities of in vitro differentiation, and avian early passage ES cells injected to host embryos were able to contribute extensively to chimeric chickens, but showed low germ line transmission [see Pain et al., 1999].

Avian PGCs segregate from the hypoblast of the germinal crescent region and begin to circulate in the embryonic bloodstream, from which they can be isolated before leaving the capillaries near the germinal epithelium to penetrate the developing gonads [Kuwana et al., 1996]. PGCs isolated from 5.5-day-old chicken embryonic germinal ridges were cultured for 5 days in medium enriched with insulin-like growth factor-1, bFGF and LIF, and contributed to the germ line of chimeric chicken following transfer into the bloodstream of host embryos [Chang et al., 1997].

\section{Rabbit}

Rabbits have several advantages over other model organisms for studies of vascular diseases, cardiomyopathy, central nervous system disorders, and abnormalities of lipoprotein metabolism. Other criteria, such as ease in housing, ability to superovulate, manipulation of embryos, and litter size make the rabbit an attractive experimental system [Graves and Moreadith, 1993]. Rabbit 
ICM cells were isolated from day 3 embryos by immunosurgery [Giles et al., 1993], or by mechanically disrupting outgrowths of day 4 to 5 blastocysts [Graves and Moreadith, 1993]. As detected by isozyme analysis and eye pigmentation rabbit ICM cells cultured on STO cells contributed to chimeric fetuses following blastocyst injection before they showed decreased mitotic activity resulting in complete differentiation after 5 passages [Giles et al., 1993]. Murine LIF preserved undifferentiated ES-like features including AP activity (fig. 1, A3) and the ability to form embryoid bodies [Graves and Moreadith, 1993; Vasilieva et al., 1998]. Following injection into blastocysts, putative rabbit ES cells contributed to fertile overt coat color chimeras, but no germ line transmission was shown [Schoonjans et al., 1996]. However, nuclear transfer resulted in development to blastocysts at a similar rate as obtained with embryonic blastomeres as nuclear donors [Du et al., 1995].

Rabbit PGCs were isolated from gonadal cells of 18 - to 22-day-old fetuses, and displayed similar characteristics as mouse PGCs regarding morphology and ultrastructure, SSEA-1 expression and AP activity [Moens et al., 1997]. Injection of rabbit PGCs after short-term culture with human LIF and bFGF into embryos between the two-cell and expanded blastocyst stage resulted in low chimerism of the developing conceptuses and liveborn offspring. When nuclei from freshly isolated male and female rabbit PGCs were transferred into enucleated oocytes, blastocyst formation of male PGC-derived embryos was higher, but no implantation sites were detected following embryo transfer to recipients [Moens et al., 1996].

\section{Rat}

The in vitro propagation and chimera production with putative rat ES cells was first reported by Iannaccone et al. [1994]. Cells derived from blastocysts and cultured on rat embryonic fibroblasts with addition of LIF displayed several characteristics of pluripotent cells, such as SSEA1 expression, AP activity, formation of embryoid bodies in vitro and of teratocarcinomas after injection into nude mice. However, the in vivo differentiation capacity of these cells (contribution to coat color chimeras) could not be confirmed by the same [Brenin et al., 1997] and other laboratories. Some rat ES-like cells cultivated for only 4 passages on homologous uterine epithelial cells were positive for AP activity and in some cases for ECMA-7 [Ouhibi et al., 1995]. In our own experiments [Vasilieva et al., unpubl. data] rat ES-like cell clones expressing AP activity, SSEA-1 and Oct-4 were established (fig. 1, B2, B3).

\section{Syrian Hamster}

Hamster putative ES cell lines were established from day 3 blastocysts and maintained undifferentiated on mouse primary embryonic fibroblast feeder layers for up to 25 passages [Doetschman et al., 1988]. In suspension, these cells formed embryoid bodies containing beating heart tissue, visceral yolk sac, endoderm cells, skeletal muscle cells and keratin swirls. However, contribution to germ line chimeras has still to be proven.

\section{Mink}

Morulae, immunosurgically isolated ICMs, or intact blastocysts have been used for the establishment of mink putative ES cell lines [Sukoyan et al., 1992, 1993]. The efficiency of suppressing differentiation and stimulating proliferation was low on primary mouse embryonic fibroblasts and established mink fibroblast cell lines [Sukoyan et al., 1992]. Morulae cultured on primary mink embryonic fibroblasts in the presence of LIF gave rise to ESlike cells capable of forming embryoid bodies in vitro and teratocarcinomas following injection into athymic mice, but these cells failed to contribute to chimeras after blastocyst injection [Sukoyan et al., 1993]. Another approach using mink blastocysts obtained after prolactin-induced termination of diapause resulted in AP-positive ES-like cells after 8 months in vitro [Polejaeva et al., 1997].

\section{Pig}

Since the pig is an excellent model for studying various human diseases, there are numerous reports concerning the culture and characterization of ICM- and PGCderived cell lines. Embryos were recovered at the desired age ranging from day 6 to 9 [Evans et al., 1990; Notarianni et al., 1990; Piedrahita et al., 1990a,b; Wheeler, 1994; Gerfen and Wheeler, 1995; Ropeter-Scharfenstein et al., 1996] and also at more advanced stages [Strojek et al., 1990; Hochereau-de Reviers and Perreau, 1993; Anderson et al., 1994; Wianny et al., 1997]. Advanced day 10 and 11 embryos appear to provide the best initial outgrowths, but tend to differentiate in vitro, while ICMs from earlier stages yield less ES cell-like colonies with a reduced tendency to differentiate during prolonged culture. However, only freshly isolated ICM cells gave rise to viable porcine chimeras after blastocyst injection [Anderson et al., 1994].

The difficulties in establishing porcine ES cells may be due to differences in embryo development, notably in the prolonged period between hatching and implantation characterized by a marked elongation of the blastocyst [Geisert et al., 1982]. During this period the ICM differ- 
entiates into the epithelial embryonic disc [Gerfen and Wheeler, 1995] which does not substantially proliferate until gastrulation, but delaminates an inner layer of primitive endoderm just after hatching [Notarianni et al., 1991] and forms vimentin expressing mesoderm-like cells [Prelle et al., 1995b]. The rapidly outgrowing trophoblast as well as the early onset of ICM differentiation require a separation of the ICM from differentiation-inducing effects prior to in vitro culture using immunosurgery [Solter and Knowles, 1975] or calcium ionophore [Prelle et al., 1993].

Much effort has been spent to optimize culture conditions supporting proliferation of undifferentiated porcine embryonic cells [Vasiliev and Vasilieva, 1995]. While homologous porcine uterine fibroblasts supported embryonic attachment and colony formation for a short time [Strojek et al., 1990], undifferentiated ICM-derived cells could be maintained on STO feeder cells for more than 1 year. Injection of the ICM-derived cells into host blastocysts resulted in the development of two chimeric porcine fetuses which were retrieved at day 30 of pregnancy [Notarianni et al., 1997]. BRL cell-conditioned medium was suitable for propagating limited undifferentiated proliferation of porcine ES-like cells [Wheeler, 1994]; however, recombinant human LIF [Moore and Piedrahita, 1997] which is highly homologous to the corresponding porcine cytokine [Wianny et al., 1997], and other heterologous cytokines were ineffective in maintaining cell lines for extended periods of time [Prelle et al., 1994, 1995a] without loosing the capability of germ line transmission [Moore and Piedrahita, 1996].

Most of the porcine embryo-derived cell lines were capable of differentiating in vitro to some extent [Evans et al., 1990; Notarianni et al., 1990] and formed teratocarcinomas after injection into nude mice [Hochereau-de Reviers and Perreau, 1993]. Porcine ES-like cells showed AP activity [Talbot et al., 1993], expressed SSEA-1 [Wianny et al., 1997], but - in contrast to murine ES cells - displayed an epithelial phenotype characterized by cytokeratin expression [Piedrahita et al., 1990b]. Recently, putative porcine ES cells displaying a morphology similar to mouse ES cells were maintained in culture for up to 44 passages and, after injection into blastocysts, contribute to chimeric offspring as assessed by the pattern of coat color and by using a genetic marker, while germ line transmission still has to be proven [Wheeler, 1994]. In vitro derived embryoid bodies originating from these cells differentiated into fibroblasts, epithelium, neurons and muscle cells [Gerfen and Wheeler, 1995].
Porcine PGCs were isolated from fetal genital ridges between days 24 and 26 post conception [Takagi et al., 1997; Piedrahita et al., 1998], but also earlier during their migration across the dorsal mesentery. In this latter stage PGCs are characterized by a higher proliferation rate and by a reduced tendency to differentiate [Shim et al., 1997]. Porcine PGCs which express SSEA-1 in vivo [Takagi et al., 1997] require STO feeder cells [Shim and Anderson, 1998], LIF, porcine SCF, but - in contrast to mouse - no bFGF for initial culture [Durcova-Hills et al., 1998]. For prolonged undifferentiated proliferation they are more responsive to cell membrane-bound [Takagi et al., 1997; Durcova-Hills et al., 1998] or homologous cytokines [Piedrahita et al., 1997].

Recently reported porcine EG cells morphologically resemble murine ES cells and consistently express AP activity [Shim et al., 1997]. These cells maintained a normal diploid karyotype, were capable of in vitro differentiation, and contributed to tissues of a liveborn chimeric piglet which, however, died after a few days. Blastocyst injection of transfected PGCs carrying the green fluorescent protein gene resulted in the birth of a chimeric piglet with contribution of transgenic cells [Piedrahita et al., 1998]. Others established several porcine EG cell lines expressing SSEA-1 and AP activity which contributed to different tissues of healthy chimeric piglets born after blastocyst injection of the transgenic EG cells [Müller et al., 1999] (fig. 1C).

\section{Cattle}

In cattle, the establishment of ES cell lines is more feasible than in the pig because large numbers of embryos can be produced in vitro; however, in vivo-derived blastocysts, especially early-hatching blastocysts, are a superior source of pluripotent cells [Talbot et al., 1995].

In cattle as in most other species the time when nuclei of embryonic cells become committed to a specific cell fate and lose their ability to direct development of different cell types limits the success of ES cell establishment [Keefer et al., 1994]. Undifferentiated cells have been isolated at any stage from 16-cell to hatched blastocyst [Strelchenko, 1996], from the latter stage mainly by immunosurgery [Sims and First, 1993; Prelle et al., 1996b]. The critical issue of getting a tight contact between feeder and embryonic cells was solved by placing the disaggregated cells under the monolayer [Stice et al., 1996].

A number of different feeder cell types have been used, including homologous granulosa cells [Strojek-Baunack et al., 1991] or fetal fibroblasts [First et al., 1994], murine fetal fibroblasts [Saito et al., 1992; Prelle et al., 1996a, 
1997] and STO cells [Talbot et al., 1995]; however, none of these feeder cell types was suitable for stimulating proliferation of embryonic cells without differentiation for an extended period of time. Supplementation of the culture medium with the heterologous human LIF did not show an effect on bovine ICM cells [Saito et al., 1992], even though bovine LIF is more similar to human than murine LIF [First et al., 1994]. The embryonic cells differentiated into a wide variety of cell types including trophectoderm which - in contrast to other species - showed AP activity [Talbot et al., 1995] while undifferentiated bovine ES cells were AP-negative [Cibelli et al., 1998a].

Sims and First [1993] maintained dissociated ICM cells in microdrop suspension culture preventing cell-tocell contact which is required for differentiation [First et al., 1994]. Cells cultured in this system for less than 28 days resulted in the birth of live calves when used as donors in nuclear transfer experiments. Stice et al. [1996] reported several ES-like cell lines which were evaluated by morphological criteria and by their ability to form embryoid bodies after more than 50 passages. Nuclear transfer embryos produced from these cells initiated pregnancies, however, they were aborted before day 60 due to incomplete placental development. This abnormality has been interpreted as a consequence of erased imprinting [Strelchenko, 1996] and could be prevented by aggregation of ES-like cells with tetraploid embryos which contribute almost exclusively to the placental tissue [Stice et al., 1996].

Cibelli et al. [1998a] established putative bovine ESlike cells which proliferated for more than 12 months without differentiation and displayed ES cell characteristics (high nuclear:cytoplasmic ratio, defined colony margins). In one approach blastocyst outgrowth was cultured and embryo-derived cells were transfected by DNA microinjection of a $\beta$-galactosidase ( $\beta$-Gal)-neomycin $(\beta-$ Geo) expression vector. The same authors transfected bovine fetal fibroblasts with $\beta$-Geo by DNA electroporation and used these cells as nuclear donors to produce transgenic blastocyst stage nuclear transfer embryos to derive ES-like cells from their ICM. Morula injection of either the embryo- or nuclear transfer-derived transgenic ES-like cells resulted in the birth of nine chimaeric calves carrying the $\beta$-Gal transgene in at least one of the tissues investigated.

In cattle, several attempts to establish pluripotent cell lines from PGCs took advantage of the cross-species similarity observed in the patterns of migration and proliferation [Leichthammer et al., 1990]. Genital ridges were obtained from fetuses between days 29 and 70 post con- ception [Cherny et al., 1994; Lavoir et al., 1994; Strelchenko, 1996; Lavoir et al., 1997] and around day 175 of gestation [Delhaise et al., 1995]. The PGCs were isolated either by enzymatic digestion or by mechanic disruption of the recovered tissues and identified by size and other morphological criteria such as large nucleus, intracytoplasmic vesicles, and occasional blebbing [Leichthammer et al., 1990]. The cells were cultured either on primary embryonic fibroblasts or on feeder layers expressing recombinant human LIF [Cherny et al., 1994], and the medium was supplemented with a 'cocktail' of human SCF, recombinant LIF and bovine bFGF [Strelchenko, 1996]. Pluripotency was evaluated by formation of embryoid bodies in vitro [Cherny et al., 1994] and by injection into blastocysts, demonstrating that FITC-labelled PGCs integrated into the ICM of a chimeric embryo [Cherny et al., 1994]. After nuclear transfer of freshly isolated bovine PGCs, developing embryos initiated pregnancies until day 40 [Delhaise et al., 1995] and 43 [Lavoir et al., 1997], respectively. Recently, the birth of one healthy calf after nuclear transfer of cultured PGCs and recloning of the developing morulae was announced [Strelchenko et al., 1998], however, another calf derived directly from freshly isolated PGCs died soon after delivery [Zakhartchenko et al., 1999a].

\section{Sheep}

For the establishment of ovine ES cells, embryos were collected between days 7 and 13 post conception [Handyside et al., 1987; Notarianni et al., 1991; Talbot et al., 1993; Galli et al., 1994; Karasiewicz et al., 1996; Meinecke-Tillmann and Meinecke, 1996]; however, the proportion of attachment to feeder cells increased when using advanced embryonic stages [Meinecke-Tillmann and Meinecke, 1996]. Isolated ICMs or embryonic discs [Notarianni et al., 1991] showed a more frequent and faster occurring attachment than intact embryos [Piedrahita et al., 1990b]. Ovine ES-like cells do not form multilayered colonies, but grow as epithelioid monolayers [Notarianni et al., 1991]. Pluripotency of the cells could be maintained only for a few passages, as shown by their ability to differentiate in vitro [Piedrahita et al., 1990b; Meinecke-Tillmann and Meinecke, 1996] and by AP activity [Talbot et al., 1993; Galli et al., 1994]. Ovine embryonic cells proliferated and differentiated relatively independent of the feeder cell type [Piedrahita et al., 1990a]. STO and BRL cells [Handyside et al., 1987], a range of species-homologous and heterologous bovine fetal feeder cell types [Meinecke-Tillmann and Meinecke, 1996], and supplementation of the culture medium with LIF were not sufficient to 
prevent spontaneous differentiation into endoderm-like [Handyside et al., 1987], mesenchymal [Karasiewicz et al., 1996] or epithelial cells [Campbell et al., 1996a]. Nevertheless the latter cells led to birth of live lambs after use in nuclear transfer experiments [Campbell et al., 1996a; Wells et al., 1997]. Attempts to prove the pluripotency of ovine embryo-derived cell lines by in vivo differentiation after injection into nude mice [Galli et al., 1994] or by chimera formation and germ line transmission after blastocyst injection [Handyside et al., 1987] failed.

\section{Nonhuman Primates}

Because of the differences between human and mouse development, anatomy, and physiology, primate models would increase the understanding of the pathogenesis of specific human diseases, such as Alzheimer's and Parkinson's disease. The cultivation of immunosurgically isolated ICMs of rhesus monkey blastocysts on a mouse embryonic fibroblast feeder layer in LIF-supplemented medium gave rise to ES-like cells which could be maintained in an undifferentiated state for more than 1 year [Thomson et al., 1995]. These cells resembled human embryonic carcinoma cells with respect to AP activity and characteristic surface markers (SSEA-3 and SSEA-4). In the absence of feeder cells, these cells differentiated into multiple cell types, and injection into immunodeficient mice resulted in teratocarcinoma formation. Eight pluripotent cell lines derived from day 8 embryos of the common marmoset [Thomson et al., 1996] were maintained in culture for more than 12 months and displayed morphological features similar to those of embryo-derived cells of rhesus monkey. Each cell line had a normal karyotype, was able to differentiate in vitro into various cell types, and formed embryoid bodies.

\section{ES Cells and Genetic Modification}

Originally, ES cells have been used for the study of early developmental processes, e.g. the clonal analysis of cell lineage in mammals, and the detection of stage- and cellspecific gene expression [Anderson, 1992]. ES cell-mediated transgenesis has some distinct advantages over other transgenic methods such as integration of (retro-)viral vectors into an early embryo or microinjection of DNA into the pronucleus of a fertilized oocyte with the difficulties of random integration of multiple copies of the introduced DNA [reviewed in Stewart, 1991]. ES cell technology might significantly increase the efficiency of producing transgenic animals, as individual cell lines derived from a single transfected cell can be screened in vitro for integration and expression of the exogenous DNA construct before creating germ line chimeric animals [Wheeler, 1994]. Because of the rapid proliferation in vitro, ES cells provide an inexhaustible supply of cells capable of homologous recombination [Capecchi, 1989]. This technique allows the precise modification of existing genes, overcomes the problems of positional effects and insertional inactivation, and mediates the inactivation of specific endogenous genes [Osterrieder and Wolf, 1998]. The reinsertion of the modified ES cell genome within the germ line provides an almost abundant source of transgenic animals [Seamark, 1994], and a method to rapidly introduce new genetic information without conventional cross-breeding [Wheeler and Choi, 1997]. Gene transfer focuses on the improvement of productivity traits (milk and carcass composition, growth rate and feed utilization) but also of disease resistance and reproductive performance [Wheeler et al., 1995]. Other important applications include the production of pharmaceutical proteins in specific organs or body fluids of transgenic animals (gene farming) [Brem and Müller, 1994], and the genetic modification of pigs to produce cells, tissues or organs for xenotransplantation [reviewed in Platt, 1998]. In addition, genetically engineered farm animals may become important animal models. The establishment of animal homologues for human diseases has proven to be an invaluable tool for studies of human genetic and infectious disorders and cancer. In particular, pigs offer some distinct advantages compared to the commonly used rodent models because they are immunologically and physiologically more similar to humans and have a more diverse genetic background [Brem and Müller, 1994; Wheeler, 1994]. Recent progress in nuclear transfer using transfected cells offers an alternative, apparently more efficient strategy for producing transgenic animals than DNA microinjection, especially in species where ES cells are not established but nuclear transfer is successfully performed (fig. 2).

\section{Potential Benefits of Totipotent and Somatic Cell Cloning}

Cloning is an asexual form of reproduction, resulting in genetically identical organisms [Anderson and Seidel, 1998]. Embryo cloning by nuclear transfer involves the transfer of genetic material from a donor cell (karyoplast) to the cytoplasm of an oocyte or zygote from which the genetic material has been removed (cytoplast). Since the 


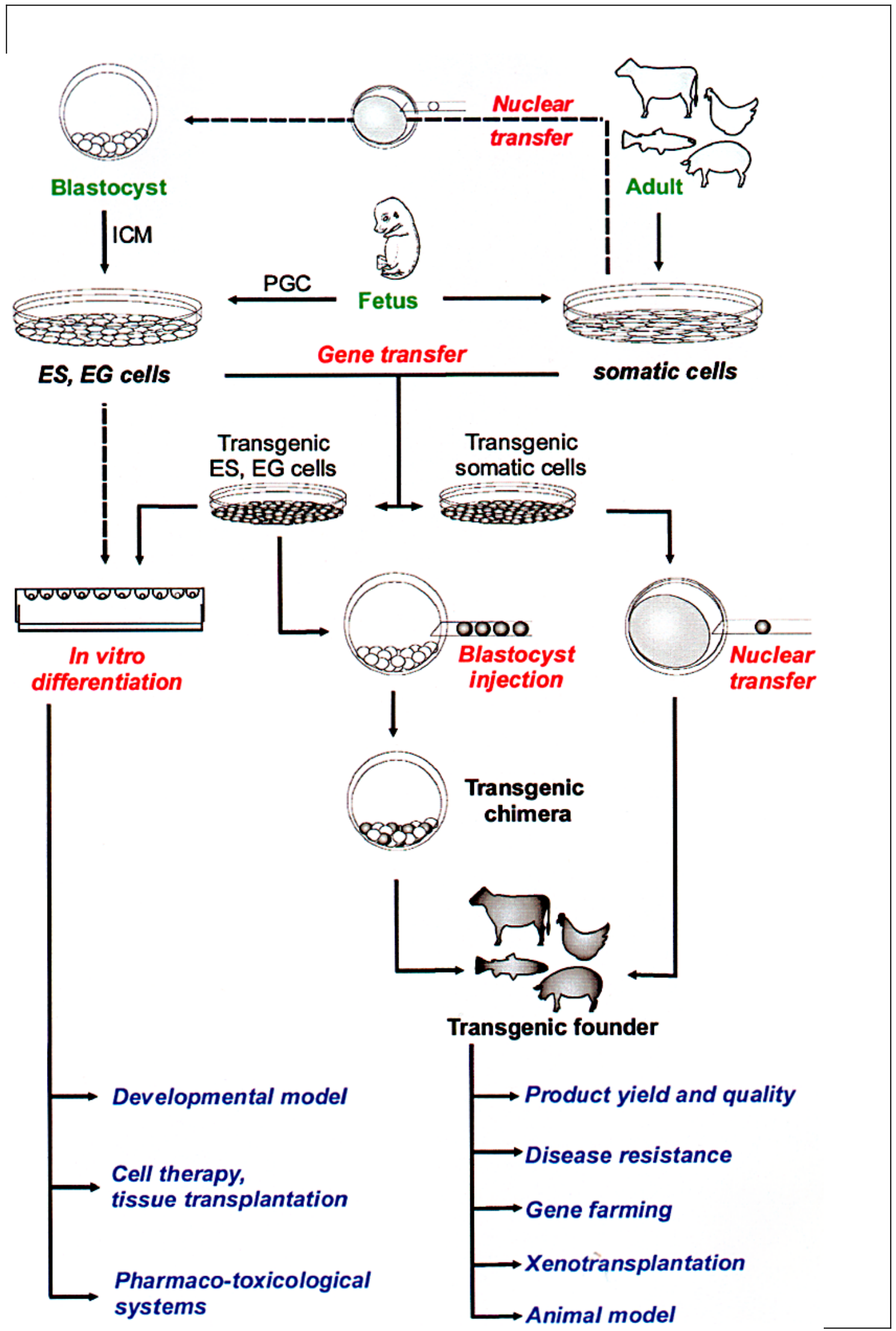


number of cells in preimplantation embryos is limited, their use as donor nuclei prohibits the generation of larger clones and also genetic modification. Recent progress in cloning animals from cultured cells of embryonic, fetal, or adult origin offers the possibility of unlimited multiplication of elite embryos or animals, and of precise genetic modification [reviewed in Wolf et al., 1998] (fig. 2). With the conventional use of ES cells via blastocyst injection or morula aggregation chimeric animals are generated and subsequent production of homozygous transgenic founder animals by conventional cross-breeding is necessary [reviewed in Stice et al., 1998]. In contrast, after the utilization of transfected presumptive ES or somatic cells as donors in nuclear transfer experiments, all offspring of the first generation will consist entirely of donor cell nuclei carrying the transgene. Also the sex of the nuclear donor cells can be determined prior to use and the problem of mosaicism in the transgenic founders resulting in failure of transgene transmission in the gametes is eliminated [Anderson and Seidel, 1998]. Production of transgenic livestock by nuclear transfer of transfected cultured cells requires fewer embryos than direct DNA microinjection into zygotes [Schnieke et al., 1997]. This implies important advantages saving time and expense particularly in large domestic animals with a long generation time and a limited number of offspring [First and Thomson, 1998].

Additionally, the availability of cultured cells for nuclear transfer allows further investigation of the cell cycle and its role in the development of cloned embryos [Campbell et al., 1996b]. Some investigators argue that forcing the donor cell into a quiescent G0 stage enhances nuclear reprogramming by switching off genes in differentiated cells [Campbell et al., 1996b]. Reprogramming includes reduction or cessation of transcription, changes in the nuclear structure (nuclear lamina), chromatin structure, nuclear morphology and stage-specific protein synthesis [reviewed in Wolf et al., 1998]. Reprogramming is also affected by the timing of embryonic genome activation [reviewed in Stice et al., 1998], which occurs at a later stage in sheep and cattle (8-cell stage), but earlier in species less amenable to nuclear transfer (mouse: 2-cell stage;

Fig. 2. Pluripotent and somatic cells as alternatives for gene and nuclear transfer in vertebrates: derivation, genetic modification and utilization via in vitro differentiation, blastocyst injection and nuclear transfer for in vitro studies, cell therapy and production of transgenic animals for different purposes. pig: 4-cell stage), leaving a shorter time period for the transferred nucleus to be reprogrammed [Solter, 1998].

However, Wakayama et al. [1998] succeeded in fullterm development of mice by simple nuclear transfer of cumulus cells. This report also underlines a series of findings initiated by Campbell et al. [1996a] suggesting that nuclei from differentiated cells introduced into enucleated oocytes are capable of supporting full development. Originally, differentiated cells have been thought to be inappropriate as nuclear donors because of apparently irreversible changes in their genome during differentiation (e.g. epigenetic methylation of cytosines). This dogma has been overcome by successful nuclear transfer using fetal cells in cattle and sheep [Schnieke et al., 1997; Wells et al., 1997; Cibelli et al., 1998b; Zakhartchenko et al., 1999b]. In the first successful cloning experiment of goats donor karyoplasts were obtained from a transgenic female fetus and one of three identical offspring produced human antithrombin III in its milk [Baguisi et al., 1999]. Fully differentiated somatic cells from adult animals used as nuclear donors, e.g. oviductal cells [Kato et al., 1998] and mural granulosa cells [Wells et al., 1999], resulted in healthy calves. However, success might be limited due to decreased and variable telomere length in the latter [Anderson and Seidel, 1998]. Mitotically inactive adult cells, such as neurons, might be poor candidates, while continuously dividing cells, such as epidermal cells, should be preferred [Wilmut et al., 1997; Wakayama et al., 1998]. Also a random loss of correct imprinting and the inactive $\mathrm{X}$ chromosome in differentiated female cells may be responsible for low full-term development of embryos derived from adult cell nuclei [Solter, 1998]. Not only a high rate of perinatal mortality but long-lasting deleterious effects might be associated with adult somatic cloning. The random choice of cultured donor cells bearing mutations or the lack of fine-tuned regulation during nucleocytoplasmic interaction are considered as epigenetic events affecting the correct reprogramming of gene activity [Renard et al., 1999].

These difficulties together with a finite life span of differentiated cells in culture also limit the types of transgenic modifications that can be made. Homologous recombination requires the selection of transfected cells and the propagation of these cells to identify the correctly targeted ones. This common strategy would be limited by a low number of cell divisions [Cibelli et al., 1998b]. Therefore, the establishment of pluripotent cells still remains a matter of scientific interest, at least as a unique source for studies of early embryonic development in respect to cell commitment and gene regulation. 


\section{Potential Applications of ES Cells and Cell Cloning to Human Biology and Medicine}

Although the recent success in establishing human ES cells raised numerous ethical concerns, acceptable applications of ES cell technology in the human can be envisaged and will be based on manipulation and analysis of human ES cells in vitro. Bongso et al. [1994] reported the isolation of human ICM cells at day 8 postinsemination and culture on ampullary epithelial feeder layers for 2 passages using human LIF. ES-like cells were identified by typical morphology and AP activity. Recently, five human ES cell lines were established from immunosurgically isolated ICMs, and at least one was maintained for more than 8 months showing similar morphology to rhesus monkey ES cells [Thomson et al., 1998]. ES-like character was demonstrated by surface marker (SSEA-3, SSEA-4) expression, AP activity, teratoma/teratocarcinoma formation in nude mice, and high telomerase activity (which is involved in maintenance of telomere length and correlates with immortality in human cell lines). Additionally, human primordial germ cells were derived from 5- to 9-week-old fetuses and cultured on STO cells with medium containing human LIF and bFGF for up to 21 days. The growing colonies were AP-positive, expressed characteristic immunological markers (SSEA-1, SSEA-3, SSEA-4), and differentiated in vitro into derivatives of all three germ layers [Shamblott et al., 1998]. In vitro differentiation of human ES cells directed along chosen pathways would allow investigation of human developmental events including regulatory signals, cell commitment and morphogenesis, and identification of target genes for new drugs and teratogenic or toxic compounds that cannot be analyzed in vivo due to ethical constraints [Rathjen et al., 1998; Thomson et al., 1998]. ES cell technology together with cloning can be useful in humans for cell and tissue therapy [Gearhart, 1998; Trounson and Pera, 1998] (fig. 2). People could provide their own cells and, by using them to replace the nuclei of their own or donor eggs, obtain stem cells in culture and then induce differentiation to provide individually tailored cell and tissue replacements without rejection problems offering lifelong treatment [Gage, 1998]. The major obstacles for gene therapy, (1) the lack of long-lived cell types easily isolated, maintained and manipulated in vitro, and (2) the possibilities of only crude modification of the human genome, could be solved by permanent human ES cell lines suitable for precise genetic modification [Rathjen et al., 1998]. But before future application of the human ES cell technology, international rules should be worked out with respect to ethical implications and the commercial use of human ES cells [see Anderson and Seidel, 1998].

\section{Acknowledgements}

We thank Dr. Sigrid Müller for providing the photographs of porcine PGCs, for many helpful comments and extended thoughtful discussions. Work was partially supported by DFG grants WO 685/2-1 and WO 685/3-1 to E.W., and by Boehringer Ingelheim and by the Fonds der Chemischen Industrie supporting A.M.W.

\section{References}

Anderson, G.B. (1992) Isolation and use of embryonic stem cells from livestock species. Anim Biotechnol 3: 165-175.

Anderson, G.B., S.J. Choi, R.H. BonDurant (1994) Survival of porcine inner cell masses in culture and after injection into blastocysts. Theriogenology 42: 204-212.

Anderson, G.B., G.E. Seidel (1998) Cloning for profit. Science 280: 1400-1401.

Baguisi, A., E. Behboodi, D.T. Melican, J.S. Pollock, M.M. Destrempes, C. Cammuso, J.L. Williams, S.D. Nims, C.A. Porter, P. Midura, M.J. Palacios, S.L. Ayres, R.S. Denniston, M.L. Hayes, C.A. Ziomek, H.M. Meade, R.A. Godke, W.G. Gavin, E.W. Overström, Y. Echelard (1999) Production of goats by somatic cell nuclear transfer. Nat Biotechnol 17: 456461 .
Beddington, R.S.P., E.J. Robertson (1989) An assessment of the developmental potential of embryonic stem cells in the mid-gestation embryo. Development 105: 733-737.

Bongso, A., C-Y. Fong, S-C. Ng, S. Ratnam (1994) Isolation and culture of inner cell mass cells from human blastocysts. Hum Reprod 11: 2110-2117.

Bradley, A., M. Evans, M.H. Kaufman, E. Robertson (1984) Formation of germ line chimeras from embryo-derived teratocarcinoma cell lines. Nature 309: 255-256.

Brem, G., M. Müller (1994) Large transgenic animals; in Maclean, N. (ed): Animals with Novel Genes. Cambridge, Cambridge University Press, pp 179-244.

Brenin, D., J. Look, N. Hübner, G. Levan, P. Iannaccone (1997) Rat embryonic stem cells: A progress report. Transplant Proc 29: 17611765.
Brook, F.A., R.L. Gardner (1997) The origin and efficient derivation of embryonic stem cells in the mouse. Proc Natl Acad Sci USA 94: 57095712.

Campbell, K.H.S., J. McWhir, W.A. Ritchie, I. Wilmut (1996a) Sheep cloned by nuclear transfer from a cultured cell line. Nature 380: 6466.

Campbell, K.H.S., W.A. Ritchie, J. McWhir, I. Wilmut (1996a) Cloning farm animals by nuclear transfer: From cell cycle to cells. Emb Trans News 14: 12-17.

Campbell, K.H.S., I. Wilmut (1997) Totipotency or multipotentiality of cultured cells: Applications and progress. Theriogenology 47: 63-72.

Capecchi, M.R. (1989) Altering the genome by homologous recombination. Science 244 : 1288-1292. 
Carsience, R.S., M.E. Clark, A.M. Verrinder Gibbins, R.J. Etches (1993) Germ line chimeric chickens from dispersed donor blastodermal cells and compromised recipient embryos. Development 117: 669-675.

Chang, I.-K., D.L. Jeong, Y.H. Hong, T.S. Park, Y.K. Moon, T. Ohno, J.Y. Han (1997) Production of germ line chimeric chickens by transfer of cultured primordial germ cells. Cell Biol Int 21: 495-499.

Cherny, R.A., T.M. Stokes, J. Merei, L. Lom, M.R. Brandon, R.L. Williams (1994) Strategies for the isolation and characterization of bovine embryonic stem cells. Reprod Fertil Dev 6: 569-575.

Cibelli, J.B., S.L. Stice, P.G. Golueke, J.J. Kane, J. Jerry, E.S. C. Blackwell, F.A. Ponce de Leon, J.M. Robl (1998a) Transgenic bovine chimeric offspring produced from somatic cell-derived stem-like cells. Nat Biotechnol 16: 642-646.

Cibelli, J.B., S.L. Stice, P.G. Golueke, J.J. Kane, J. Jerry, E.S.C. Blackwell, F.A. Ponce de Leon, J.M. Robl (1998b) Cloned transgenic calves produced from nonquiescent fetal fibroblasts. Science 280: 1256-1258.

Collodi, P., Y. Kamei, A. Sharps, D. Weber, D. Barnes (1992) Fish embryo cell cultures for derivation of stem cells and transgenic chimeras. Mol Mar Biol Biotechnol 1: 257-265.

Conover, J.C., N.Y. Ip, W.T. Poueymirou, B. Bates, M.P. Goldfarb, T.M. DeChiara, G.D. Yancopoulos (1993) Ciliary neutrophic factor maintains the pluripotentiality of embryonic stem cells. Development 119: 559-565.

Delhaise, F., V. Bralion, N. Schuurbiers, F. Dessy (1996) Establishment of an embryonic stem cell line from 8-cell stage mouse embryos. Eur J Morphol 34: 237-243.

Delhaise, F., F.J. Ectors, R. De Roover, F. Ectors, F. Dessy (1995) Nuclear transplantation using bovine primordial germ cells from male fetuses. Reprod Fertil Dev 7: 1217-1219.

Doetschman, T.C., H.R. Eistetter, M. Katz, W. Schmidt, R. Kemler (1985) The in vitro development of blastocyst-derived embryonic stem cell lines: Formation of visceral yolk sac, blood islands and myocardium. J Embryol Exp Morphol 87: 27-45.

Doetschman, T.C., P. Williams, N. Maeda (1988) Establishment of hamster blastocyst-derived embryonic stem (ES) cells. Dev Biol 127: 224227.

Du, F., J.R. Giles, R.H. Foote, K.H. Graves, X. Yang, R.W. Moreadith (1995) Nuclear transfer of putative rabbit embryonic stem cells leads to normal blastocyst development. J Reprod Fertil 104: 219-223.

Durcova-Hills, G., K. Prelle, S. Müller, M. Stojkovic, J. Motlik, E. Wolf, G. Brem (1998) Primary culture of porcine PGCs requires LIF and porcine membrane-bound stem cell factor. Zygote 6: 271-275.

Eddy, E.M., J.M. Clark, D. Gong, B.A. Fenderson (1981) Origin and migration of primordial germ cells in mammals. Gamete Res 4: 333362 .
Eistetter, H.R. (1989) Pluripotent embryonal stem cell lines can be established from disaggregated mouse morulae. Dev Growth Differ 31: 275 282.

Etches, R.J., M.E. Clark, A. Toner, G. Liu, A.M. Verrinder Gibbins (1996) Contribution to somatic and germ line lineage of chicken blastodermal cells maintained in culture. Mol Reprod Dev 45: 291-298.

Evans, M.J., M.B.L. Carlton, A.P. Russ (1997) Gene trapping and functional genomics. Trends Genet 13: 370-374.

Evans, M.J., M.H. Kaufman (1981) Establishment in culture of pluripotential cells from mouse embryos. Nature 292: 154-156.

Evans, M.J., E. Notarianni, S. Laurie, R.M. Moor (1990) Derivation and preliminary characterization of pluripotent cell lines from porcine and bovine blastocysts. Theriogenology 33: 125-128.

First, N.L., M.M. Sims, S.P. Park, M.J. Kent-First (1994) Systems for production of calves from cultured bovine embryonic cells. Reprod Fertil Dev 6: 553-562.

First, N.L., J. Thomson (1998) From cows stem therapies? Nat Biotechnol 16: 620-621.

Gage, F.H. (1998) Cell therapy. Nature 392(suppl): 18-24.

Galli, C., G. Lazzari, J.E. Flechon, R.M. Moor (1994) Embryonic stem cells in farm animals. Zygote 2: 385-389.

Gearhart, J. (1998) New potential for human embryonic stem cells. Science 282: 1061-1062.

Geisert, R.D., J.W. Brookbank, R.M. Roberts, F.W. Bazer (1982) Establishment of pregnancy in the pig. II. Cellular remodelling of the porcine blastocyst during elongation on day 12 of pregnancy. Biol Reprod 27: 941-955.

Gerfen, R.W., M.B. Wheeler (1995) Isolation of embryonic cell lines from porcine blastocysts. Anim Biotechnol 6: 1-14.

Giles, J.R., X. Yang, W. Mark, R.H. Foote (1993) Pluripotency of cultured rabbit inner cell mass cells detected by isozyme analysis and eye pigmentation of fetuses following injection into blastocysts or morulae. Mol Reprod Dev 36: 130-138.

Graves, K.H., R.W. Moreadith (1993) Derivation and characterisation of putative pluripotential embryonic stem cells from preimplantation rabbit embryos. Mol Reprod Dev 36: 424433.

Handyside, A., M.L. Hooper, M.H. Kaufman, I. Wilmut (1987) Towards the isolation of embryonal stem cell lines. Rouxs Arch Dev Biol 196: 185-190.

Hochereau-de Reviers, T.M., C. Perreau (1993) in vitro culture of embryonic disc cells from porcine blastocysts. Reprod Nutr Dev 33: 475483.

Hong, Y., M. Schartl (1996) Establishment and growth responses of early medakafish (Oryzias latipes) embryonic cells in feeder layer-free cultures. Mol Mar Biol Biotechnol 5: 93-104.

Hong, Y., C. Winkler, M. Schartl (1996) Pluripotency and differentiation of embryonic stem cell lines from the medakafish (Oryzias latipes). Mech Dev 60: 33-44.
Hong, Y., C. Winkler, M. Schartl (1998) Production of medakafish chimeras from a stable embryonic stem cell line. Proc Natl Acad Sci USA 95: 3679-3684.

Iannaccone, P.M., G.U. Taborn, R.L. Garton, M.D. Caplice, R.D. Brenin (1994) Pluripotent embryonic stem cells from the rat are capable of producing chimeras. Dev Biol 163: 288292.

Karasiewicz, J., E. Szablisty, A. Guszkiewicz, M. Kossakowski, G. Stefanski, M. Reed, J. Modlinski (1996) Development of isolated sheep inner cell masses/embryonic discs in vitro. Rouxs Arch Dev Biol 205: 437-442.

Kato, Y., T. Tani, Y. Sotomaru, K. Kurokawa, J. Kato, H. Doguchi, H. Yasue, Y. Tsunoda (1998) Eight calves cloned from somatic cells of a single adult. Science 282: 2095-2098.

Keefer, C.L., S.L. Stice, D.L. Matthews (1994) Bovine inner cell mass cells as donor nuclei in the production of nuclear transfer embryos and calves. Biol Reprod 50: 935-939.

Kuwana, T., K. Hashimoto, A. Nakanishi, Y. Yasuda, A. Tajima, M. Naito (1996) Long-term culture of avian embryonic cells in vitro. Int J Dev Biol 40: 1061-1064.

Labosky, P.A., D.P. Barlow, B.M.L. Hogan (1994) Mouse embryonic germ (EG) cell lines: Transmission through the germ line and differences in the methylation imprint of insulin-like growth factor 2 receptor (Igf2r) gene compared with embryonic stem (ES) cell lines. Development 120: 3197-3204.

Lavoir, M.-C., P.K. Basrur, K.J. Betteridge (1994) Isolation and identification of germ cells from fetal bovine ovaries. Mol Reprod Dev 37: 413424.

Lavoir, M.-C., N. Rumph, A. Moens, W.A. King, Y. Plante, W.H. Johnson, J. Ding, K.J. Betteridge (1997) Development of bovine nuclear transfer embryos made with oogonia. Biol Reprod 56: 194-199.

Leichthammer, F., E. Baunack, G. Brem (1990) Behaviour of living primordial germ cells of livestock in vitro. Theriogenology 33: 12211230.

Mann, J.R., I. Gadi, M.L. Harbison, S.J. Abbondanzo, C.L. Stewart (1990) Androgenetic mouse embryonic stem cells are pluripotent and cause skeletal defects in chimeras: Implications for genetic imprinting. Cell 62: 251-260.

Martin, G. (1981) Isolation of a pluripotent cell line from early mouse embryos cultured in medium conditioned by teratocarcinoma stem cells. Proc Natl Acad Sci USA 78: 7634-7638.

Martin, G.R., M.J. Evans (1975) Differentiation of clonal lines of teratocarcinoma cells: Formation of embryoid bodies in vitro. Proc Natl Acad Sci USA 72: 1441-1445.

Matsui, Y., K. Zsebo, B.L.M. Hogan (1992) Derivation of pluripotential embryonic stem cells from murine primordial germ cells in culture. Cell 70: 841-847.

McWhir, J., A.E. Schnieke, R. Ansell, H. Wallace, A. Colman, A.R. Scott, A.J. Kind (1996) Selective ablation of differentiated cells permits isolation of embryonic stem cell lines from murine embryos with a non-permissive genetic background. Nat Genet 14: 223-226. 
Meinecke-Tillmann, S., B. Meinecke (1996) Isolation of ES-like cell lines from ovine and caprine pre-implantation embryos. J Anim Breed Genet 113: 413-426.

Modlinski, J.A., M.A. Reed, T.E. Wagner, J. Karasiewicz (1996) Embryonic stem cells: Developmental capabilities and their possible use in mammalian embryo cloning. Anim Reprod Sci 42: 437-446.

Moens, A., S. Chastant, P. Chesne, J.-E. Flechon, K.J. Betteridge, J.-P. Renard (1996) Differential ability of male and female rabbit fetal germ cell nuclei to be reprogrammed by nuclear transfer. Differentiation 60: 339-345.

Moens, A., B. Flechon, J. Degrouard, X. Vignon, J. Ding, J.-E. Flechon, K.J. Betteridge, J.-P. Renard (1997) Ultrastructural and immunocytochemical analysis of diploid germ cells isolated from fetal rabbit gonads. Zygote 5: 47-60.

Moore, K., J.A. Piedrahita (1996) Effects of heterologous hematopoietic cytokines on in vitro differentiation of cultured porcine inner cell masses. Mol Reprod Dev 45: 139-144.

Moore, K., J.A. Piedrahita (1997) The effects of human leukemia inhibitory factor (HLIF) and culture medium on in vitro differentiation of cultured porcine inner cell mass (PICM). In Vitro Cell Dev Biol Anim 33: 62-71.

Müller, S., K. Prelle, N. Rieger, C. Lassnig, U. Luksch, H. Petznek, B. Aigner, M. Baetscher, E. Wolf, M. Müller, G. Brem (1999) Chimeric pigs following blastocyst injection of transgenic porcine primordial germ cells. Mol Reprod Dev, in press.

Nagy, A., E. Gocza, E.M. Diaz, V.R. Prideaux, E. Ivanyi, M. Markkula, J. Rossant (1990) Embryonic stem cells alone are able to support fetal development in the mouse. Development 110: 815-821.

Nichols, J., I. Chambers, A. Smith (1994) Derivation of germ line competent embryonic stem cells with combination of interleukin-6 and soluble interleukin-6 receptor. Exp Cell Res 215: 237-239.

Nichols, J.F., E.P. Evans, A.G. Smith (1990) Establishment of germ line-competent embryonic stem (ES) cells using differentiation inhibiting activity. Development 110: 1341-1348.

Notarianni, E., C. Galli, S. Laurie, R.M. Moor, M.J. Evans (1991) Derivation of pluripotent, embryonic cell lines from the pig and sheep. $\mathrm{J}$ Reprod Fertil Suppl 43: 255-260.

Notarianni, E., S. Laurie, R.M. Moor, M.J. Evans (1990) Maintenance and differentiation in culture of pluripotential embryonic cell lines from pig blastocysts. J Reprod Fertil Suppl 41: 5156.

Notarianni, E., S. Laurie, A. Ng, K. Sathasivam (1997) Incorporation of cultured embryonic cells into transgenic and chimeric porcine fetuses. Int J Dev Biol 41: 537-540.

Osterrieder, N., E. Wolf (1998) Lessons from gene knockouts. Rev Sci Tech 17: 351-364.

Ouhibi, N., N.F. Sullivan, J. English, W.H. Colledge, M.J. Evans, N.J. Clark (1995) Initial culture behaviour of rat blastocysts on selected feeder cell lines. Mol Reprod Dev 40: 311324.
Pain, B., P. Chenevier, J. Samarut (1999) Chicken ES cells and transgenic strategies. Cells Tissues Organs 165: 212-219.

Pain, B., M.E. Clark, M. Shen, H. Nakazawa, M. Sakura, J. Samarut, R.J. Etches (1996) Longterm in vitro culture and characterisation of avian embryonic stem cells with multiple morphogenic potentialities. Development 122: 2339-2348.

Pease, S., P. Braghetta, D. Gearing, D. Grail, R.L. Williams (1990) Isolation of embryonic stem (ES) cell lines in media supplemented with recombinant leukemia factor (LIF). Dev Biol 141: 344-352.

Pedersen, R.A. (1994) Studies of in vitro differentiation with embryonic stem cells. Reprod Fertil Dev 6: 543-552.

Petitte, J.N., M.E. Clark, G. Liu, A.M. Verrinder Gibbins, R.J. Etches (1990) Production of somatic and germ line chimeras in the chicken by transfer of early blastodermal cells. Development 108: 185-189.

Piedrahita, J.A., G.B. Anderson, R.H. BonDurant (1990a) Influence of feeder layer type on the efficiency of isolation of porcine embryo-derived cell lines. Theriogenology 34: 865-877.

Piedrahita, J.A., G.B. Anderson, R.H. BonDurant (1990b) On the isolation of embryonic stem cells: A comparative behaviour of murine, porcine and ovine embryos. Theriogenology 34 : 879-901.

Piedrahita, J.A., K. Moore, C. Lee, B. Oetama, R. Weaks, J. Ramsoondar, J. Thomson, J. Vasquez (1997) Advances in the generation of transgenic pigs via embryo-derived and primordial germ cell-derived cells. J Reprod Fertil Suppl 52: 245-254.

Piedrahita, J.A., K. Moore, B. Oetama, C.-K. Lee, N. Scales, J. Ramsoondar, F.W. Bazer, T. Ott (1998) Generation of transgenic porcine chimeras using primordial germ cell-derived colonies. Biol Reprod 58: 1321-1329.

Platt, J.L. (1998) New directions for organ transplantation. Nature 392(suppl): 11-17.

Polejaeva, I.A., W.A. Reed, T.D. Bunch, L.C. Ellis, K.L. White (1997) Prolactin-induced termination of obligate diapause of mink (Mustela vison) blastocysts in vitro and subsequent establishment of embryonic stem-like cells. J Reprod Fert 109: 229-230.

Prelle, K., H. Füllgrabe, W. Holtz (1993) Isolation of the inner cell mass (ICM) for the establishment of embryonic stem cells (abstract). J Reprod Fertil Abstr Ser 12: 6.

Prelle, K., W. Holtz, M. Osborn (1995a) The intermediate filament protein vimentin as differentiation marker in preimplantation porcine embryos (abstract). Biol Reprod 52(suppl): 177.

Prelle, K., F. Sinowatz, E. Wolf (1997) Effects of different thiol compounds on the ultrastructure of inner cell mass cells of bovine embryos (abstract). Theriogenology 47: 244.

Prelle, K., M. Stojkovic, G. Brem, E. Wolf (1996a) Isolation of bovine inner cell masses for the establishment of pluripotent cell lines $(a b-$ stract). Proc 13th Int Congr Anim Reprod, P21-6.
Prelle, K., M. Stojkovic, M. Brielmeier, E. Wolf (1996b) Beneficial effects of thiol compounds on hatching rate and ICM outgrowth of bovine IVM/IVF embryos (abstract). Biol Reprod 54(suppl): 172

Prelle, K., A.M. Wobus, W. Holtz (1995b) Porcine inner cell masses grow undifferentiated in the presence of STO cells and bFGF (abstract). J Reprod Fertil Abstr Ser 15: 72

Prelle, K., A.M. Wobus, E. Wolf, N. Neubert, W. Holtz (1994) Effects of growth factors on the in vitro development of porcine inner cell masses isolated by calcium ionophore A23187 (abstract). J Reprod Fertil Abstr Ser 13: 41

Rathjen, P.D., J. Lake, L.M. Whyatt, M.D. Bettess, J. Rathjen (1998) Properties and uses of embryonic stem cells: Prospects for application to human biology and gene therapy. Reprod Fertil Dev 10: 31-47.

Renard, J.-P., S. Chastant, P. Chesne, C. Richard, J. Marchal, N. Cordonnier, P. Chavatte, X. Vignon (1999) Lymphoid hypoplasia and somatic cloning. Lancet 353: 1489-1491.

Resnick, J.L., L.S. Bixler, L. Cheng, P.L. Donovan (1992) Long-term proliferation of mouse primordial germ cells in culture. Nature 359: 550551

Robertson, E.J. (1987) Embryo-derived stem cell lines; in Robertson EJ (ed): Teratocarcinomas and Embryonic Stem Cells: A Practical Approach. Oxford, IRL Press, pp 71-112.

Robertson, E.J. (1997) Derivation and maintenance of embryonic stem cell cultures. Methods Mol Biol 75: 173-184.

Rohwedel, J., U. Sehlmeyer, J. Shan, A. Meister, A.M. Wobus (1996) Primordial germ cell-derived mouse embryonic germ (EG) cells in vitro resemble undifferentiated stem cells with respect to differentiation capacity and cell cycle distribution. Cell Biol Int 20: 579-587.

Rohwedel, J., K. Guan, A.M. Wobus (1999) Induction of cellular differentiation by retinoic acid in vitro. Cells Tissues Organs 165: 190-202.

Ropeter-Scharfenstein, M., N. Neubert, K. Prelle, W. Holtz (1996) Identification, isolation, and culture of pluripotent cells from the porcine inner cell mass. J Anim Breed Gen 113: 427436.

Rose, T.M., G. Bruce (1994) Oncostatin M is a member of a cytokine family that includes leukaemia inhibitory factor, granulocyte colony stimulating factor, and interleukin-6. Proc Natl Acad Sci USA 88: 8641-8645.

Saito, S., N. Strelchenko, H. Niemann (1992) Bovine embryonic stem cell-like lines cultured over several passages. Rouxs Arch Dev Biol 201: 134-141.

Schnieke, A.E., A.J. Kind, W.R. Ritchie, K. Mycock, A.R. Scott, M. Ritchie, I. Wilmut, A. Colman, K.S. Campbell (1997) Human factor IX transgenic sheep produced by transfer of nuclei from transfected fetal fibroblasts. Science 278 : 2130-2133.

Schöler, H.R., A.K. Hatzopoulos, R. Balling, N. Suzuki, P. Gruss (1989) A family of octamer specific proteins present during mouse embryogenesis: Evidence for germ line-specific expression of an Oct factor. EMBO J 8: 25432550 . 
Schoonjans, L., G.M. Albricht, J.-L. Li, D. Collen, R.W. Moreadith (1996) Pluripotential rabbit embryonic stem (ES) cells are capable of forming overt coat colour chimeras following injection into blastocysts. Mol Reprod Dev 45: 439443.

Seamark, R.F. (1994) Progress and emerging problems in livestock transgenesis: A summary perspective. Reprod Fertil Dev 6: 653-657.

Shamblott, M.J., J. Axelman, S. Wang, E.M. Bugg, J.W. Littlefield, P.J. Donovan, P.D. Blumenthal, G.R. Huggins, J.D. Gearhart (1998) Derivation of pluripotent stem cells from cultured human primordial germ cells. Proc Natl Acad Sci USA 95: 13726-13731.

Shim, H., G.B. Anderson (1998) In vitro survival and proliferation of porcine primordial germ cells. Theriogenology 49: 521-528.

Shim, H., A. Gutierrez-Adan, L.R. Chen, R.H. BonDurant, E. Behboodi, G.B. Anderson (1997) Isolation of pluripotent stem cells from cultured porcine primordial germ cells. Biol Reprod 57: 1089-1095.

Sims, M., N.L. First (1993) Production of calves by transfer of nuclei from cultured inner cell mass cells. Proc Natl Acad Sci USA 90: 6143-6147.

Smith, A.G., J.K. Heath, D.D. Donaldson, G.G. Wong, J. Moreau, M. Stahl, D. Rogere (1988) Inhibition of pluripotential embryonic stem cell differentiation by purified polypeptides. Nature 336: 688-690.

Smith, A.G., M.L. Hooper (1987) Buffalo rat liver cells produce a diffusible activity which inhibits the differentiation of murine embryonal carcinoma and embryonic stem cells. Dev Biol 121: 1-9.

Solter, D. (1998) Dolly is a clone - and no longer alone. Nature 394: 315-316.

Solter, D., B.B. Knowles (1975) Immunosurgery of mouse blastocyst. Proc Natl Acad Sci USA 72: 5099-5102.

Solter, D., B.B. Knowles (1978) Monoclonal antibody defining a stage-specific mouse embryonic antigen (SSEA-1). Proc Natl Acad Sci USA 75: 5565-5569.

Stewart, C.L. (1991) Prospects for the establishment of embryonic stem cells and genetic manipulation of domestic animals; in Pedersen, R.A., A. McLaren, N.L. First (eds): Animal Applications of Research in Mammalian Development. Cold Spring Harbor, Cold Spring Harbor Laboratory Press, pp 267-283.

Stewart, C.L., I. Gadi, H. Bhatt (1994) Stem cells from primordial germ cells can reenter the germ line. Dev Biol 161: 626-628.

Stice, S.L., J.M. Robl, F.A. Ponce de Leon, J. Jerry, P.G. Golueke, J.B. Cibelli, J.J. Kane (1998) Cloning: New breakthroughs leading to commercial opportunities. Theriogenology 48: 129-138.

Stice, S.L., N.S. Strelchenko, C.L. Keefer, L. Matthews (1996) Pluripotent bovine embryonic cell lines direct development following nuclear transfer. Biol Reprod 54: 100-110.

Strelchenko, N. (1996) Bovine pluripotent stem cells. Theriogenology 45: 131-140.
Strelchenko, N., J. Betthauser, G. Jurgella, E. Farsberg, P. Damiani, P. Golueke (1998) Use of somatic cells in cloning (abstract). Proc Gen Engineering Cloning Anim, Park City.

Strojek, R.M., M.A. Reed, J.L. Hoover, T.E. Wagner (1990) A method for cultivation morphologically undifferentiated embryonic stem cells from porcine blastocysts. Theriogenology 33: 901-913.

Strojek-Baunack, R.M., K. Bürkle, K. Burich, S. Hense, C. Reintjes, J. Hahn (1991) Kokultivierung von Rinderblastozysten unter verschiedenen Bedingungen in vitro. Fertilität 7: 77-84.

Sukoyan, M.A., A.N. Golubitsa, A.I. Zhelezova, A.G. Shilov, S.Y. Vatolin, L.P. Maximovsky, L.E. Andreeva, J. McWhir, S.D. Pack, S.I. Bayborodin, A.Y. Kerkis, H.I. Kizilova, O.L. Seov (1992) Isolation and cultivation of blastocystderived stem cell lines from American mink (Mustela vison). Mol Reprod Dev 33: 418431.

Sukoyan, M.A., S.Y. Vatolin, A.N. Golubitsa, A.I Zhelezova, L.A. Semenova, O.L. Serov (1993) Embryonic stem cells derived from morulae, inner cell mass, and blastocysts of mink: Comparisons of their pluripotencies. Mol Reprod Dev 36: 148-158.

Sun, L., C.S. Bradford, G. Ghosh, P. Collodi (1995) ES-like cell cultures derived from early zebrafish embryos. Mol Mar Biol Biotechnol 4: 193 199.

Takagi, Y., N.C. Talbot, C.E. Rexroad, V.G. Pursel (1997) Identification of pig primordial germ cells by immunocytochemistry and lectin binding. Mol Reprod Dev 46: 567-580.

Talbot, N.C., A.M. Powell, C.E. Rexroad (1995) In vitro pluripotency of epiblast derived from bovine blastocysts. Mol Reprod Dev 42: 35-52.

Talbot, N.C., C.E. Rexroad, V.G. Pursel, A.M. Powell (1993) Alkaline phosphatase staining of pig and sheep epiblast cells in culture. Mol Reprod Dev 36: 139-147.

Thomas, K.R., M.R. Capecchi (1987) Site-directed mutagenesis by gene targeting in mouse embryo-derived stem cells. Cell 51: 503-512.

Thomson, J.A., J. Itskovitz-Eldor, S.S. Shapiro, M.A. Waknitz, J.J. Swiergiel, V.S. Marshall, J.M. Jones (1998) Embryonic stem cell lines derived from human blastocysts. Science 282: 1145-1147.

Thomson, J.A., J. Kalishman, T.G. Golos, M. Durning, C.P. Harris, R.A. Becker, J.P. Hearn (1995) Isolation of a primate embryonic stem cell line. Proc Natl Acad Sci USA 92: 78447848.

Thomson, J.A., J. Kalishman, T.G. Golos, M Durning, C.P. Harris, J.P. Hearn (1996) Pluripotent cell lines derived from common marmoset (Callithrix jacchus) blastocysts. Biol Reprod 55: 254-259.

Thoraval, P., F. Lasserre, F. Coudert, G. Dambrine (1994) Somatic and germline chicken chimeras obtained from brown and white Leghorns by transfer of early blastodermal cells. Poul Sci 73: 1897-1905.

Trounson, A., M. Pera (1998) Potential benefits of cell cloning for human medicine. Reprod Fertil Dev 10: 121-125.
Van Stekelenburg-Hamers, A.E.P., T.A.E. Van Achterberg, H.G. Rebel, J.-E. Flechon, K.H.S. Campbell, S.M. Weima, C.L. Mummery (1995) Isolation and characterization of permanent cell lines from inner cell mass cells of bovine blastocysts. Mol Reprod Dev 40: 444454

Vasiliev, I.M., S.G. Vasilieva (1995) Factors influencing the isolation of embryonic stem cells of pigs. Russ J Dev Biol 26: 163-166.

Vasilieva, S.G., K. Prelle, S. Müller, U. Besenfelder, M. Müller, G. Brem (1998) Establishment and long-term culture of rabbit ES cells. Russ J Dev Biol 5: 347-353.

Wakamatsu, Y., K. Ozato, T. Sasado (1994) Establishment of a pluripotent cell line derived from a medaka (Oryzias latipes) blastula embryo. Mol Mar Biol Biotechnol 3: 185-191.

Wakayama, T., A.C.F. Perry, M. Zuccotti, K.R. Johnson, R. Yanagimachi (1998) Full-term development of mice from enucleated oocytes injected with cumulus cell nuclei. Nature 394: 369-374.

Wang, Z.Q., F. Kiefer, P. Urbanek, E.F. Wagner (1997) Generation of completely embryonic stem cell-derived mutant mice using tetraploid blastocyst injection. Mech Dev 62: 137-145.

Wells, D.N., P.M. Misica, T.A.M. Day, H.R. Tervit (1997) Production of cloned lambs from an established embryonic cell line: A comparison between in vivo- and in vitro-matured cytoplasts. Biol Reprod 57: 385-393.

Wells, D.N., P.M. Misica, H.R. Tervit (1999) Production of cloned calves following nuclear transfer with cultured adult mural granulosa cells. Biol Reprod 60: 996-1005.

Wheeler, M.B. (1994) Development and validation of swine embryonic stem cells: A review. Reprod Fertil Dev 6: 563-568

Wheeler, M.B., S.-J. Choi (1997) Embryonic stem cells and transgenics: Recent advances. Arq Fac Vet UFRGS 25(suppl): 64-83.

Wheeler, M.B., A.L. Rund, G.T. Bleck (1995) The use of embryonic stem cells in the production of transgenic livestock. Emb Trans News 13: $20-25$.

Wianny, F., C. Perreau, M.T. Hochereau-de Reviers (1997) Proliferation and differentiation of porcine inner cell mass and epiblast in vitro. Biol Reprod 57: 756-764.

Wilmut, I., A.E. Schnieke, J. McWhir, A.J. Kind, K.H.S. Campbell (1997) Viable offspring derived from fetal and adult mammalian cells. Nature 385: 810-813.

Wobus, A.M., K. Guan (1998) Embryonic stem cell-derived cardiac differentiation: Modulation of differentiation and 'loss-of-function' analysis in vitro. Trends Cardiovasc Med 8: 64-74.

Wobus, A.M., H. Holzhausen, P. Jäkel, J. Schöneich (1984) Characterization of a pluripotent stem cell line derived from a mouse embryo. Exp Cell Res 152: 212-219. 
Wobus, A.M., G. Kaomei, J. Shan, M.-C. Wellner, J. Rohwedel, J. Guanju, B. Fleischmann, H.A. Katus, J. Hescheler, W.-M. Franz (1997a) Retinoic acid accelerates embryonic stem cell-derived cardiac differentiation and enhances development of ventricular cardiomyocytes. J Mol Cell Cardiol 29: 1525-1529.

Wobus, A.M., J. Rohwedel, V. Maltsev, J. Hescheler (1994) In vitro differentiation of embryonic stem cells into cardiomyocytes or skeletal muscle cells is specifically modulated by retinoic acid. Rouxs Arch Dev Biol 204:36-45.

Wobus, A.M., J. Rohwedel, C. Strübing, J. Shan, K. Adler, V. Maltsev, J. Hescheler (1997b) In vitro differentiation of embryonic stem cells; in Klug, S, R. Thiel (eds): Methods in Developmental Toxicology and Biology. Berlin, Blackwell Science, pp 1-17.
Wobus, A.M., G. Wallukat, J. Hescheler (1991) Pluripotent mouse embryonic stem cells are able to differentiate into cardiomyocytes expressing chronotropic responses to adrenergic and cholinergic agents and $\mathrm{Ca}^{2+}$ channel blockers. Differentiation 48: 173-182.

Wolf, E., R. Kramer, I. Polejaeva, H. Thoenen, G. Brem (1994) Efficient generation of chimeric mice using embryonic stem cells after longterm culture in the presence of ciliary neurotrophic factor. Transgenic Res 3: 152-158.

Wolf, E., R. Kramer, H. Thoenen, G. Brem (1996) Alternative culture systems for mouse embryonic stem cells; in Arnold, W., P. KöpfMaier, B. Micheel (eds): Immunodeficient Animals: Models for Cancer Research. Contrib Oncol. Basel, Karger, pp 214-218.

Wolf, E., V. Zakhartchenko, G. Brem (1998) Nuclear transfer in mammals: Recent developments and future perspectives. J Biotechnol 65 : 99-110.
Wood, S.A., N.D. Allen, J. Rossant, A. Auerbach, A. Nagy (1993) Non-injection method for the production of embryonic stem cell-embryo chimeras. Nature 365: 87-89.

Wylie, C.C. (1993) The biology of primordial germ cells. Eur Urol 23: 62-67.

Zakhartchenko, V., G. Durcova-Hills, W. Schernthaner, M. Stojkovic, H.-D. Reichenbach, S. Müller, R. Steinborn, M. Müller, H. Wenigerkind, K. Prelle, E. Wolf, G. Brem (1999a) Potential of fetal germ cells for nuclear transfer in cattle. Mol Reprod Dev 52: 421-426.

Zakhartchenko, V., G. Durcova-Hills, M. Stojkovic, W. Schernthaner, K. Prelle, R. Steinborn, M. Müller, G. Brem, E. Wolf (1999b) Effects of serum starvation and recloning on the efficiency of nuclear transfer using bovine fetal fibroblasts. J Reprod Fertil 115: 325-331. 